\title{
NIH: a strategy for the 21st century?
}

\begin{abstract}
When the US National Institutes of Health get a new leader, important decisions will have to be made about funding strategies and research support if they are to continue as a paradigm of scientific excellence.
\end{abstract}

CONTRARY to trends of recent decades, the research budget of the US National Institutes of Health (NIH), now $\$ 10.3$ billion, is not likely to keep up with inflation next year when it is expected to receive an increase of only 3.3 per cent. Furthermore, most of that meagre increase has already been allocated to special causes through a process well-known as political 'earmarking'. Often thought of as a tendency of the Congress (where earmarked projects are known as 'pork'), this time it is clear that the administration of President Bill Clinton is every bit as capable of playing politics with research budgets as is the Congress.

Clinton's budget proposal, which cumulatively would reduce funding for research in the basic biomedical sciences broadly while focusing dollars on AIDS, women's health (particularly breast cancer), minority health and the human genome project - all areas that are fashionable these days and supported by influential lobbying or advocacy groups, whereas other scientifically ripe disciplines (neuroscience, for example) are left behind. It would appear that the Clinton administration has accepted the notion that targeted research will buy cures for disease. (In other agencies, notably the National Science Foundation, Clinton has requested substantial increases.)

In this environment, NIH needs a strong leader whose experience is well-grounded in serious research and who has the personal and administrative talent it will take to guide the institutes through difficult times. To its credit, the administration has acquiesced in the idea of a search committee of academics to find a replacement for the current head of NIH, cardiologist Bernadine P. Healy, whose resignation was requested by the White House. Healy will leave at the end of June. Meanwhile, the search committee, named by Donna Shalala, the Secretary of Health and Human Services, and Philip R. Lee, who has been nominated but not confirmed as assistant secretary for health, has been diligently combing the country for Healy's successor.

The search committee, headed by biologist Bruce Alberts (who will become president of the US National Academy of Sciences in July) has the confidence of the biomedical research community, where morale is at an all-time low despite the excitement of this unusually productive era in science. And the people with whom the committee has talked about the NIH directorship have the credentials to be taken seriously as candidates. Among them are William
Danforth, chancellor of Washington University in St Louis; Harold Varmus of the University of California at San Francisco (who would be the first NIH director to hold a Nobel prize); Yale University provost Judith Rodin; Patricia K. Donahoe of Harvard's Massachusetts General Hospital; Stanford University dean David Korn; and Herbert Pardes, dean of medicine at Columbia University. Others will be interviewed during the next few days.

At this point, this journal does not favour one candidate over another. However, it is imperative that President Clinton (or perhaps Hilary Rodham Clinton if the task falls to her) should confine themselves to the search committee's list of candidates when making a final selection. The administration's track record for appointments throughout the new government has been marred by over-zealous attention to the requirement that every list of potential jobholders "look like America", as Clinton puts it. The US biomedical research enterprise is one of the country's most valuable intellectual assets and its leader should be selected for qualities that match the intellectual and academic requirements of the job. It will be a sorry day if, in the end, the White House ignores the work of its NIH search committee.

One of the new director's first challenges will be to come to grips with Healy's most tangible legacy - a "strategic" plan for NIH research into the twenty-first century that is about to be released in the form of a glossy 100-page report called Investment for Humanity. Nearly two years in the writing, the strategic plan grew out of Healy's quite sensible idea that a $\$ 10$ billion enterprise, like any large business, should periodically take stock of itself in an organized fashion. That the plan got off on the wrong foot almost from the start because it was regarded by the outside community as the province of a hand-chosen group of Healy supporters within NIH should not detract from the rightness of its goal.

Today the NIH consists of 24 separate institutes, centres and divisions, most operating with a congressionally assigned budget and each only loosely responsible to the NIH director. Healy, perhaps influenced by her previous experience in the Republican White House where she served in the Office of Science and Technology Policy, approached strategic planning with a business executive's confidence. Not surprisingly, that rattled more traditional scientists who cling to the idea that science cannot be planned. In truth, to some extent it can. That is, one can identify areas of 
scientific opportunity where good ideas are plentiful and imaginative experiments can be proposed.

But the tendency is to equate medical or social need with scientific opportunity and, to some extent, that has emerged in the final version of the plan, which also says the "right" things about most of modern biology. Thus, the health needs of women and minorities are given several paragraphs. But molecular medicine, computational biology, gene therapy and vaccine development are also emphasized, along with the need to attend to the training of the next generation of researchers and the importance of maintaining the public's trust in science by ensuring an enterprise that is ethical and free of fraud. In short, the plan (as might be inevitable) covers a good deal of scientific territory.

But more than that, it makes a couple of important and entirely controversial statements about the relationship between NIH and the US economy that should become the subject of open and informed debate among the research community. Namely, the plan states that NIH is (and should be) a major force in the US economy (through the pharmaceutical and biotechnology industries, for example) and it takes the line that "NIH discoveries and their applications have a positive impact on one of the Nation's most intractable social and economic problems - containing and reducing health care costs". On the face of it, that is not only an arguable statement but a questionable goal for an enterprise grounded in basic research that may not lack the will but does lack the means to keep any promise to reduce health care costs. Science does not work that way. Unless research leads to simple, inexpensive and complete prevention or cure of disease (childhood immunization comes to mind) it cannot take credit for major cost savings. Similarly, it is simplistic to blame high-technology medicine for rising costs. To suggest that NIH plays a significant part in the health care cost crisis is to misunderstand the complex financial and social elements of that crisis. NIH should stick to its scientific knitting.

\section{Free telecommunications}

\section{Europe's plan for electronic services had better be adventurous. If it is not, it will fail.}

IN the now standard European style, the telecommunications ministers of Europe will this week have been considering the future of their industry in the 12 member states. The logic is straightforward. If the concept of a free market means that German cabbages can be freely sold throughout Europe, then why not German telephone calls or Minitel boxes like those that have given France access to database services of a kind that ordinary people use? That is the theory, which the member states have in principle accepted. European telecommunications are indeed to be liberalized. But there is a long way to go before the principle will be turned into reality, despite the European Commission's hope that everything can be settled less than five years from now, in time for 1 January 1998.

The difficulties are not merely that most major communications businesses in Europe are still closely identified with their governments, but that there are technical questions still unresolved. Residual chauvinism is nevertheless certain to be a hindrance. In many countries France, Germany and Belgium, for example - the general opinion is for liberalization, but at some point in the future more distant than 1998. But much has changed in a short time. Even previously obdurate governments have been driven to sell their PTTs (postal, telephone and telegraph companies) to private owners by the difficulty of raising from public funds the capital they need to keep abreast of quickly moving technology. The idea that there should be international competition from within Europe is catching on. So why not also face up to the idea of competition from outside, from AT\&T of the United States for example? That is where most PTTs find their nerves on edge.

With good reason. Both in Britain and in Denmark, telecommunications services are already controlled by private companies convinced that they have more to gain from open international competition than from a strictly European canvas. British Telecom, the chief British operator, is even seeking the right to provide trunk telephone and other services in the United States - and may be allowed to do so if AT\&T is given a reciprocal right to operate in Britain. The most powerful impetus for a European policy is the fear that, without one, wider competition will simply take root and be ineradicable. That explains why change is in the air.

The technical obstacles to change are not unalloyed difficulties, but also opportunities. They consist of mobile telephone systems operated through Earth satellites, the use of cable television networks for carrying broad-band signals into homes and other premises and the prospect that the old dream of integrating computer systems with telecommunications networks will yet become a reality. The threat to the investment in the old order from mobile telephones is already substantial in Europe, accounting for one out of every eight telephone calls. And while most European governments have so far followed the United States in requiring that PTTs should not be allowed to distribute television signals, it is an inefficient use of resources to require that the increasingly sophisticated telephone network should be operated in parallel with a cable network that could do the same jobs.

What all this implies is that technological advances in the past few years guarantee that change is unavoidable, and will probably be more rapid than anybody has been supposing. Already, for example, there is nothing to prevent, say, a South Korean telephone company from providing Europe with telephone services by means of satellites launched from China. Whatever may be the present arrangements between European governments and their PTTs, the monopolies of the past would in practice be broken. That is why it would be best for Europe if its governments would go the whole hog, settling for radical competition and quickly. 